\title{
Isolasi Bakteri Karbonoklastik dari Pegunungan Kapur
}

\author{
Gian Rukmana dan Enny Zulaika \\ Departemen Biologi, Fakultas Ilmu Alam, Institut Teknologi Sepuluh Nopember (ITS) \\ e-mail: enny@bio.its.ac.id
}

\begin{abstract}
Abstrak-Bakteri karbonoklastik adalah bakteri yang dapat menghasilkan kalsium karbonat $\left(\mathrm{CaCO}_{3}\right)$. Presipitasi $\mathrm{CaCO}_{3}$ oleh bakteri dikarenakan adanya aktifitas urease yang menghidrolisis urea menjadi amonium sehingga meningkatkan pH lingkungan dan membentuk ion karbonat, yang selanjutnya berikatan dengan ion kalsium terbentuk $\mathrm{CaCO}_{3}$. Inokulum bakteri karbonoklastik diisolasi dari pegunungan kapur di Gresik , Bangkalan dan Tuban . Isolasi menggunakan medium selektif CCP (Calcium Carbonate Precipitation). Koloni yang tumbuh dipurifikasi selanjutnya dilakukan uji konfirmasi keberadaan urease. Isolat terpilih di identifikasi dengan panduan Bergey's Manual of Determinative Bacteria. Semua isolat yaitu SG 2, SG 3, SG 4, SG 5 (dari Gresik), JB 2 , JB 3 (dari Bangkalan), AT 2, AT 3 (dari Tuban) dapat menghasilkan urease dan membentuk kristal $\mathrm{CaCO}_{3}$. Isolat SG 3, SG 4, JB 2 , JB 3, AT 2, AT 3 teridentifikasi sebagai genus Bacillus, isolat SG 2 terindentifikasi sebagai genus Sulfidobacillus dan isolat SG 5 teridentifikasi sebagai genus Escherichia.
\end{abstract}

Kata Kunci-Bakteri Karbonoklastik, $\mathrm{CaCO}_{3}, \quad$ Generic Assignment, Urease.

\section{PENDAHULUAN}

B AKTERI karbonoklastik adalah bakteri yang dapat menghasilkan kalsium karbonat $\left(\mathrm{CaCO}_{3}\right)$. Bakteri karbonoklastik dapat ditemukan di pegunungan kapur, guagua karst ataupun di sedimen, beberapa bakteri tersebut diantaranya dari anggota genus Sporosarcina, Bacillus, Brevundimonas serta Lysinibacillus [1]. Bakteri karbonoklastik berpotensi untuk memperkuat struktur beton. Biobeton dengan penambahan bakteri karbonoklastik terbukti bermanfaat untuk struktur konstruksi tahan lama dan juga memperbaiki sifat beton serta mengurangi biaya perawatan beton [2].

Menurut [3], bakteri karbonoklastik yang mampu menghasilkan kristal $\mathrm{CaCO}_{3}$ berpotensi digunakan sebagai biobeton untuk memperkuat struktur beton. Jika terdapat retak mikro pada struktur beton, bakteri mampu berfungsi sebagai self-healing concrete yang artinya memperbaiki retak mikro pada beton secara otomatis. Beberapa penelitian menyebutkan, bakteri karbonoklastik dapat digunakan untuk meningkatkan kekuatan beton dan merekatkan retak rambut pada beton. Bakteri karbonoklastik (Bacillus) mempunyai endospora yang dapat bergerminasi ketika air dan udara masuk melalui retakan mikro dalam beton dan akan membentuk kristal $\mathrm{CaCO}_{3}$ sehingga dapat memperbaiki retak mikro pada beton. Berdasarkan penelitian [4], pembentukan $\mathrm{CaCO}_{3}$ oleh bakteri dikarenakan hidrolisis urea oleh urease yang menghasilkan amonium dan karbonat. Amonium bertindak untuk menaikkan $\mathrm{pH}$ lingkungan yang merupakan kondisi menguntungkan untuk pengendapan $\mathrm{CaCO}_{3}$. Karbonat mengikat ion kalsium dan menghasilkan pembentukan kristal $\mathrm{CaCO}_{3}$ yang diendapkan lingkungan. Berdasarkan fenomena diatas, dilakukan penelitian isolasi, identifikasi bakteri karbonoklastik yang dapat membentuk kristal $\mathrm{CaCO}_{3}$ sehingga dapat digunakan untuk memperkuat struktur beton.

\section{METODOLOGI}

\section{A. Waktu dan Tempat Penelitian}

Penelitian ini dilakukan di Laboratorium Mikrobiologi dan Bioteknologi Departemen Biologi FMIPA ITS Surabaya pada bulan Januari sampai dengan Mei 2017. Lokasi sampling isolat bakteri karbonoklastik di daerah Pegunungan Suci, Kecamatan Manyar, Kabupaten Gresik. Bukit Jaddih, Desa Jaddih, Kecamatan Socah, Kabupaten Bangkalan. Gua Akbar, Desa Gedongombo, Semanding, Kecamatan Tuban, Kabupaten Tuban.

\section{B. Isolasi dan Purifikasi Bakteri}

Sample didapatkan dengan mengambil material kapur, dimasukkan kedalam botol sample steril, ditutup, dilabel dan disimpan. Sampel dihaluskan dengan menggunakan mortal dan pastle, dimasukkan dalam larutan fisiologis $(0,9 \% \mathrm{NaCl})$, dilakukan pengenceran yang bertingkat. Sampel diambil sebanyak $100 \mu \mathrm{L}$ dituang pada cawan yang berisi media selektif dengan metode spread plate. Media selektif yang digunakan adalah media Calcium Carbonate Precipitation (CCP) dengan komposisi (per liter) $20 \mathrm{~g}$ urea; 2,12 $\mathrm{g}$ $\mathrm{NaHCO}_{3} ; 10 \mathrm{~g} \mathrm{NH}_{4} \mathrm{Cl} ; 3$ gr Natrium Broth; $30 \mathrm{mM} \mathrm{CaCl}_{2} ; 20$ $\mathrm{g}$ agar, $\mathrm{pH}$ diatur 8,5 dengan $\mathrm{NaOH} 2 \mathrm{M}$ [4]. Isolat kemudian diinkubasi pada suhu ruang selama 7 hari.

Koloni yang tumbuh adalah isolat bakteri karbonoklastik. Koloni dipurifikasi sampai diperoleh kultur murni. Satu isolat diambil secara aseptis dengan jarum ose, diinokulasikan ke media CCP dengan metode 16 goresan dan diinkubasi pada suhu ruang \pm 24 jam. Koloni yang tumbuh diamati sampai diperoleh koloni yang seragam.

\section{Uji Kualitatif Enzim Urease}

Isolat terpilih diuji aktivitas ureasenya secara kualitatif di media urea cair. Per $100 \mathrm{ml}$ mengandung 0,9 gr urea basebroth dan $5 \mathrm{ml}$ urea $40 \%$. Isolat diambil sebanyak 1 ose, kemudian diinokulasi pada media urea cair $5 \mathrm{ml}$, diinkubasi pada suhu ruang selama 1-2 hari. Jika terjadi warna dari kuning menjadi merah muda menunjukkan isolat tersebut menghasilkan enzim urease. Dipilih 3 isolat yang menghasilkan enzim urease yang lebih tinggi yang menunjukkan warna lebih merah dibanding isolat lainnya [5]. 
Tabel 1.

Isolat Bakteri Pengendap $\mathrm{CaCO}_{3}$

\begin{tabular}{cccccc}
\hline \hline Isolat & $\mathrm{CaCO}_{3}$ & Isolat & $\mathrm{CaCO}_{3}$ & Isolat & $\mathrm{CaCO}_{3}$ \\
\hline $\mathrm{SG} 1$ & + & JB 1 & + & AT 1 & + \\
SG 2 & + & JB 2 & + & AT 2 & + \\
SG 3 & + & JB 3 & + & AT 3 & + \\
SG 4 & + & JB 4 & + & AT 4 & + \\
SG 5 & + & JB 5 & + & AT 5 & + \\
\hline \hline
\end{tabular}

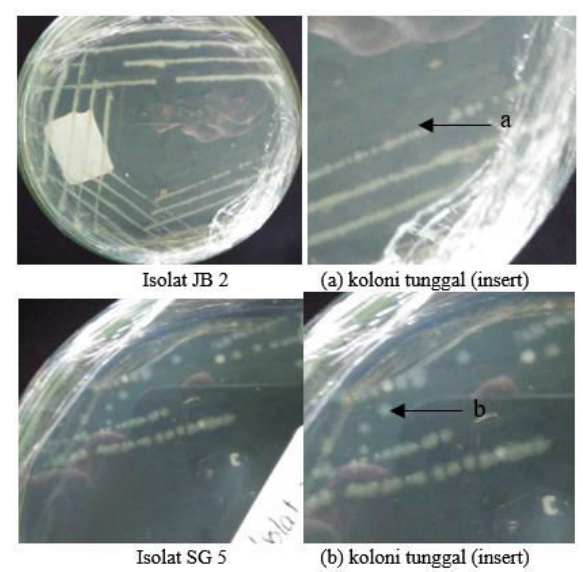

Gambar 1. Purifikasi Isolat JB 2 dan SG 5 dengan Metode Gores 16.

\section{Identifikasi Bakteri}

Isolat terpilih di identifikasi berdasarkan buku panduan Bergey's Manual of Determinative Bacteria. Identifikasi berdasarkan morfologi sel, sifat Gram, pewarnaan endospora, motilitas, uji kebutuhan oksigen dan uji katalase [6].

\section{HASIL DAN DISKUSI}

\section{A. Isolasi \& Purifikasi Bakteri}

Isolat bakteri yang berasal dari sampel tanah kapur kawasan daerah Pegunungan Suci, Gresik, Bukit Jaddih, Bangkalan serta Gua Akbar, Tuban ditumbuhkan pada Medium CCP (Calcium Carbonate Precipitation). Proses isolasi bakteri dilakukan dengan cara melarutkan 1 gram sampel tanah kapur dalam $9 \mathrm{ml}$ akuades steril dan dihomogenkan dengan menggunakan vortex. Kemudian dilanjutkan dengan pengenceran bertingkat hingga konsentrasi $10^{-6}$. Hal ini dilakukan supaya didapatkan jumlah bakteri yang tidak terlalu padat. Pengenceran bertingkat berfungsi agar koloni bakteri yang tumbuh dalam media agar plate tidak mencapai 300 koloni [7]. Dari pengenceran $10^{-1}$ hingga $10^{-6}$ diambil masingmasing 0,1 ml untuk diinokulasikan pada Medium CCP (Calcium Carbonate Precipitation) dalam cawan petri.

Isolat bakteri yang tumbuh merupakan bakteri karbonoklastik yang dapat membentuk $\mathrm{CaCO}_{3}$. Koloni yang tumbuh membentuk butiran kristal dan diindikasikan sebagai $\mathrm{CaCO}_{3}$ sebab bakteri diisolasi dengan medium selektif CCP agar terseleksi bakteri dengan kode SG yang berasal dari Pegunungan Suci yaitu SG 1, SG 2, SG 3, SG 4 dan SG 5. Bakteri dengan kode JB yang berasal dari Bukit Jaddih, Bangkalan yaitu JB 1, JB 2, JB 3, JB 4 dan JB 5. Bakteri dengan kode AT yang berasal dari Gua Akbar, Tuban yaitu AT 1, AT 2, AT 3, AT 4 dan AT 5 dapat dilihat pada Tabel 1.
Tabel 2.

\begin{tabular}{cccccc}
\multicolumn{7}{c}{ Hasil Uji Kualitatif Enzim Urease } \\
\hline \hline Isolat & Hasil & Isolat & Hasil & Isolat & Hasil \\
\hline SG 1 & - & JB 1 & - & AT 1 & - \\
SG 2 & + & JB 2 & + & AT 2 & + \\
SG 3 & + & JB 3 & + & AT 3 & + \\
SG 4 & + & JB 4 & - & AT 4 & - \\
SG 5 & + & JB 5 & - & AT 5 & - \\
\hline \hline
\end{tabular}

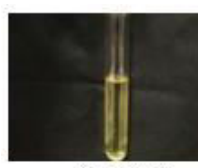

Kontrol

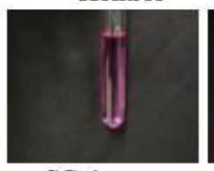

SG 4

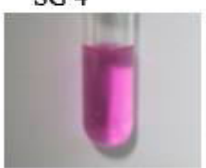

JB 3

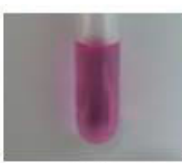

SG 2

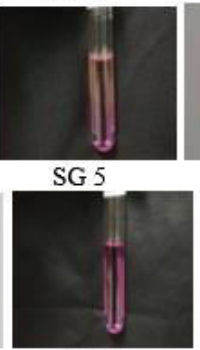

AT 2

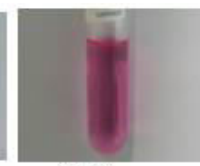

SG 3

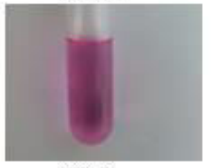

JB 2

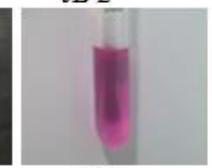

AT 3
Gambar 2. Hasil Uji Kualitatif Keberadaan Enzim Urease.

Kemudian dilakukan pemurnian dengan metode 16 gores pada medium CCP baru dengan tujuan mendapatkan kultur murni bakteri. Pemurnian dengan menggunakan metode 16 gores dapat mempermudah proses pemurnian karena memiliki prinsip kerja goresan bertingkat (Gambar 1).

Mikroorganisme akan terlepas dari jarum ose sepanjang permukaan agar. Pada arah menuju akhir goresan hanya sedikit sel bakteri yang tersisa pada jarum ose, sehingga individu sel bakteri akan tumbuh pada tempat yang berbeda di permukaan agar. Jika medium yang digunakan mengandung nutrisi yang dibutuhkan oleh bakteri untuk tumbuh, sel tunggal membentuk mikrokoloni. Mikrokoloni kemudian terus tumbuh menjadi koloni [8].

\section{B. Uji Kualitatif Adanya Enzim Urease}

Urease disebut juga urea amidohidrolase merupakan enzim yang mengkatalis hidrolisis dari urea menjadi ammonia dan karbonat. Urease merupakan enzim sitosolik dan umum ditemukan pada bakteri, yeast, dan beberapa tumbuhan [9]. Enzim ini menggunakan urea sebagai substrat yang akan dihidrolisis menjadi amonia dan asam karbonat sebagai produk akhir. Urease berperan dalam memudahkan organisme menggunakan urea sebagai sumber nitrogen [10][11].

Uji kualitatif enzim urease dilakukan pada semua isolat yang terseleksi. Dari 15 isolat, terseleksi 8 isolat yang dapat menghasilkan enzim urease ditandai dengan perubahan warna kuning menjadi warna merah muda. Kedelapan isolat tersebut adalah SG 2, SG 3, SG 4, SG 5, JB 2, JB 3, AT 2 dan AT 3. Isolat lainnya tidak terjadi perubahan warna sehingga isolat tersebut diindikasikan tidak dapat membentuk $\mathrm{CaCO}_{3}$ ditunjukkan pada Tabel 2 dan Gambar 2.

Kemampuan bakteri membentuk $\mathrm{CaCO}_{3}$ dikarenakan bakteri toleran terhadap konsentrasi urea dan kalsium yang tinggi. Bakteri akan menghasilkan urease akan menghidrolisis 
urea sehingga melepas ion karbonat $\left(\mathrm{CO}_{3}{ }^{2-}\right)$ ' selanjutnya $\mathrm{CO}_{3}{ }^{2-}$ akan terikat dengan ion kalsium $\left(\mathrm{Ca}^{2+}\right)$ dari $\mathrm{CaCl}_{2}$ dan membentuk $\mathrm{CaCO}_{3}$ dan $\mathrm{H}_{2} \mathrm{O}$ [12].

\section{Identifikasi Genus}

Menurut [13], identifikasi dan Generic Asistment digunakan untuk mengidentifikasi apakah isolat termasuk anggota genus yang sudah ada atau genus baru (novel). Identifikasi dilakukan dengan menggunakan panduan Bergey's Manual of Determinative Bacteriology [14]. Identifikasi terhadap 8 isolat menggunakan profile matching dengan karakter kunci sesuai genus masing-masing. Hasil identifikasi genus selengkapnya dapat dilihat pada Tabel 3 sampai 5.

Tabel 3.

Identifikasi dengan Profile Matching

\begin{tabular}{|c|c|c|c|c|c|c|c|c|}
\hline No & $\begin{array}{c}\text { Karakter } \\
\text { kunci Bacillus }\end{array}$ & Bacillus & $\underset{n}{m}$ & $\begin{array}{r}ナ \\
\mho\end{array}$ & $\stackrel{N}{n}$ & $\stackrel{m}{n}$ & Ẽ & $\stackrel{m}{\rightleftarrows}$ \\
\hline 1 & Sel Batang & + & + & + & + & + & + & + \\
\hline 2 & Gram & + & + & + & + & + & + & + \\
\hline 3 & Motilitas & + & + & + & + & + & + & + \\
\hline 4 & Endospora & + & + & + & + & + & + & + \\
\hline 5 & $\begin{array}{c}\text { Aerob/ } \\
\text { Fakultatif } \\
\text { anaerob }\end{array}$ & $-/+$ & $-/+$ & $-/+$ & $-/+$ & $-/+$ & $-/+$ & $-/+$ \\
\hline 6 & Katalase & + & + & + & + & + & + & + \\
\hline
\end{tabular}

Berdasarkan Tabel 3, isolat SG 3, SG 4, JB 2, JB 3, AT 2 dan AT 3 diidentifikasi sebagai genus Bacillus. Menurut [14], genus Bacillus mempunyai karakter kunci sel batang, Gram positif, motil, memiliki endospora, bersifat aerob/fakultatif anaerob, dan katalase positif.

Tabel 4.

Identifikasi dengan Profile Matching

\begin{tabular}{cccc}
\hline \hline \multicolumn{4}{c}{ Identifikasi dengan Profile Matching } \\
No & Karakter kunci & Sulfidobacillus & SG 2 \\
\hline 1 & Sulfidobacillus & + & + \\
2 & Sel Batang & + & + \\
3 & Gram & - & - \\
4 & Motilitas & + & + \\
5 & Endospora & $+/-$ & $+/-$ \\
6 & Aerob/ Fakultatif & + & + \\
\hline \hline
\end{tabular}

Berdasarkan Tabel 4 isolat SG 2 diidentifikasi sebagai genus Sulfidobacillus. Menurut [14], genus Sulfidobacillus mempunyai karakter kunci sel batang, Gram positif, motil, memiliki endospora, bersifat aerob/fakultatif anaerob, dan katalase positif.

Tabel 5.

Identifikasi dengan Profile Matching

\begin{tabular}{cccc}
\hline \hline No & Karakter kunci & & \\
& Escherichia & Escherichia & SG 5 \\
\hline 1 & Sel Batang & + & + \\
2 & Gram & - & - \\
3 & Motilitas & + & + \\
4 & Endospora & - & - \\
5 & Aerob/ Fakultatif anaerob & $-/+$ & $-/+$ \\
6 & Katalase & + & + \\
\hline \hline
\end{tabular}

Berdasarkan Tabel 5 isolat SG 5 diidentifikasi sebagai genus Escherichia. Menurut [14], genus Escherichia mempunyai karakter kunci sel batang, Gram negatif, motil, tidak memiliki endospora, bersifat aerob/fakultatif anaerob, dan katalase positif.

\section{KESIMPULAN}

Isolasi sampel kapur dari pegunungan kapur didapatkan 15 isolat karbonoklastik yaitu SG 1, SG 2, SG 3, SG 4, SG 5, JB 1, JB 2, JB 3, JB 4, JB 5, AT 1, AT 2, AT 3, AT 4 dan AT 5. Genus bakteri karbonoklastik yang positif menghasilkan urease adalah genus Bacillus ( SG 2,SG 3, SG 4, JB 2, JB 3, AT 2, AT 3), genus Sufidobacillus (SG2) dan genus Escherichia (SG 5).

\section{UCAPAN TERIMA KASIH}

Penulis mengucapkan terimakasih kepada Dr. Enny Zulaika, MP. atas dukungannya melalui pendanaan PNBP ITS tahun anggaran 2016 No. Kontrol 01711/IT2.11/PN.08/2016.

\section{DAFTAR PUSTAKA}

[1] Dhami, N. Kaur, M. S. Reddy, and A. Mukherjee., "Biomineralization of Calcium Carbonate Polymorphs by the Bacterial Strains Isolated from Calcareous Sites," J. Microbiol. Biotechnol., vol. 23, no. 5, 2013.

[2] J. Bashir, Ifrahkathwari, Tiwary, and A. Khushpreetsingh, "Bio Concrete The Self Healing Concrete," Indian J. Sci. Technol., vol. 9, no. 47, 2016.

[3] W. Jianyun, Y. C. Ersan, N. Boon, and N. De Belie, "Application Of Microorganisms In Concrete: A Promising Sustainable Strategy To Improve Concrete Durability," Appl Microbiol Biotechnol, vol. 100, no. 7, pp. 2993-3007, 2016.

[4] S. Wei, H. Cui, Z. Jiang, H. Liu, H. He, and N. Fang, "Biomineralization processes of calcite induced by bacteria isolated from marine sediments," Brazilian J. Microbiol., vol. 2, no. 46, pp. 455-464, 2015.

[5] F. Hammes, N. Boon, and J. Villiers, "Strain-specific ureolytic microbial calcium carbonate precipitation," Appl Env. Microbiol, vol. 69, pp. 49014909, 2003.

[6] J. P. Harley and L. M. Prescott, Laboratory Exercises in Microbiology. USA: Mc Graw Hill, 2002

[7] J. h. Corry, J. Atabay, Forsythes, and L. Mansfield, Culture media for the isolation of campylobacters, helicobacter and arcobacters. In: Handbook of Culture Media for Food Microbiology. Amsterdam: Elsevier, 2003.

[8] J. Slonczewski and J.W. Foster, Microbiology: An Evolving Science. New York: CSHI Press, 2009.

[9] B. Sujoy and A. Aparna, "Enzymology, Immobilization and Application of Urease Enzyme," Int. Res. J. Biol. Sci, vol. 2, pp. 51-56, 2013.

[10]B. Krajewska, "Ureases 1. Functional, Catalytic and Kinetic Properties: A review," Sci. Res. Essays, vol. 7, pp. 2104-2111, 2009.

[11]Y. Qin and J. M. S. Cabral, "Properties and Applications of Urease: A review," Biocatal. Biotransformation, vol. 20, pp. 1-14, 2002.

[12]V. P. L.A et al., "Scale Up Of Biogrout: a Biological Ground Reinforcement Method," in Proceeding of the 17th International Conferences on Soil Mechanics and Geotechnical Engineering, 2009, pp. 2328-2333.

[13]E. Zulaika, "Eksplorasi Bakteri Resisten Merkuri (BRM) Endogenik Kalimas Surabaya yang Berpotensi Sebagai Kandidatus Agensia Bioremediasi Pencemaran Merkuri," Universitas Airlangga, 2013.

[14]J. G. Holt, N. R. Krieg, P. H. A. Sneath, J. . Staley, and S. . Williams, Bergey's Manual of Determinative Bacteriology. Philadelphia: Lippincot Williams \& Wilkins, 1994. 